\title{
The Meaning of Life and Life Satisfaction Among International Students at University Putra Malaysia (UPM) During the Covid-19 Pandemic
}

Ratna Roshida Ab Razak, Lee Yok Fee, Ahmad Nasir Mohd Yusoff, Zarina Muhammad \& Yang Zhijia

To Link this Article: http://dx.doi.org/10.6007/IJARBSS/v11-i12/11786

DOI:10.6007/IJARBSS/v11-i12/11786

Received: 20 October 2021, Revised: 23 November 2021, Accepted: 10 December 2021

Published Online: 26 December 2021

In-Text Citation: (Razak et al., 2021)

To Cite this Article: Razak, R. R. A., Fee, L. Y., Yusoff, A. N. M., Muhammad, Z., \& Zhijia, Y. (2021). The Meaning of Life and Life Satisfaction Among International Students at University Putra Malaysia (UPM) During the Covid-19 Pandemic. International Journal of Academic Research in Business and Social Sciences, 11(12), 392-406.

\section{Copyright: @ 2021 The Author(s)}

Published by Human Resource Management Academic Research Society (www.hrmars.com)

This article is published under the Creative Commons Attribution (CC BY 4.0) license. Anyone may reproduce, distribute, translate and create derivative works of this article (for both commercial and non0-commercial purposes), subject to full attribution to the original publication and authors. The full terms of this license may be seen at: http://creativecommons.org/licences/by/4.0/legalcode

Vol. 11, No. 12, 2021, Pg. $392-406$

Full Terms \& Conditions of access and use can be found at http://hrmars.com/index.php/pages/detail/publication-ethics 


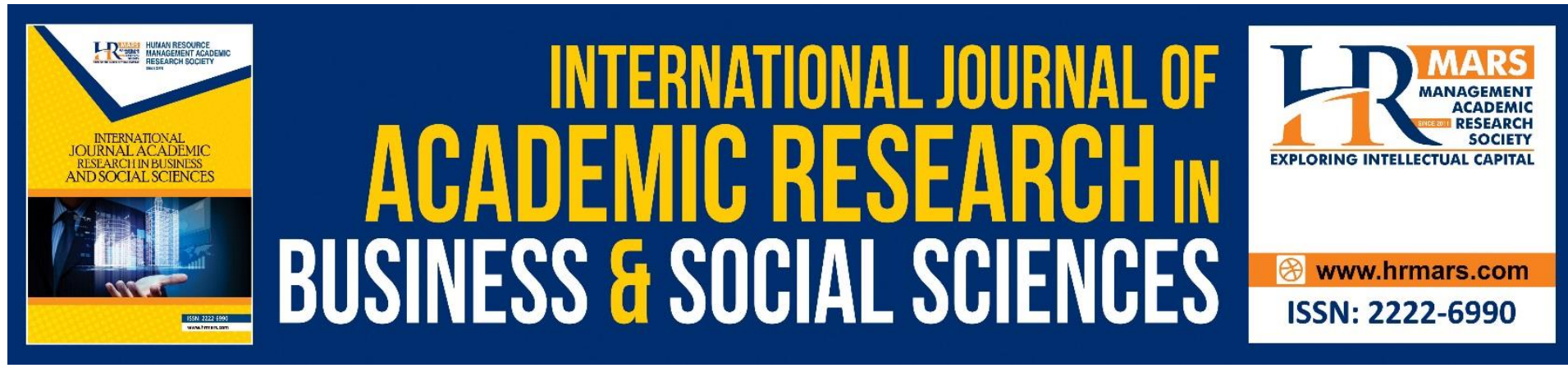

\title{
The Meaning of Life and Life Satisfaction Among International Students at University Putra Malaysia (UPM) During the Covid-19 Pandemic
}

\author{
Ratna Roshida Ab Razak, Lee Yok Fee, Ahmad Nasir Mohd \\ Yusoff, Zarina Muhammad \& Yang Zhijia \\ Department of Government and Civilization Studies, Faculty of Human Ecology
}

Universiti Putra Malaysia, 43400 Serdang, Selangor

Email: ratna_razak@upm.edu.my

\begin{abstract}
This study is an attempt to examine a sense of existential meaning or meaning of life and life satisfaction among the international students amid a period of volatility, uncertainty, complexity, and ambiguity (VUCA), particularly in light of the tragic COVID-19 pandemic. The participants were 204 international students. They were recruited to respond to two sets of questionnaires namely Meaning in life using (MLQ) developed by Steger (2010) and the Satisfaction with Life Scale (SWLS) was first created by researchers Diener, Emmons, Larsen, and Griffin (1985). The results indicated that a positive relationship was found between meaning in life and life satisfaction among international students during the COVID-19 pandemic. This significant relationship found between the meaning of life and life satisfaction among the international students, could lead them to adjust, embrace and change lives and turn the tragedy into a time of resilience, strength, knowledge and a new environment of mutual and communal living, sharing responsibilities and appreciating solidarity. This finding matches with the previous research that has shown that a capacity to behave with insight and humility while preserving inner and outer harmony irrespective of the circumstances has also been found to be a key component in increasing life satisfaction.
\end{abstract}

Keywords: Meaning of Life, Life Satisfaction, International Students, VUCA, COVID-19

\section{Introduction}

It is impossible to overestimate the significance of meaning in life to one's psychological and physical health and well-being. Researchers have just recently begun to investigate the presence and search for meaning in life as distinct structures. The Meaning of Life Questionnaire, which assesses the existence of meaning and the search for meaning, as well as measures of well-being, was completed by 203 international students from UPM in the current study. Presence and the search for meaning in life had a variety of consequences on life satisfaction, all of which led to happiness. The presence of meaning was positively correlated with life satisfaction, in line with previous studies, while the quest for meaning had the opposite pattern of correlates. Those who already had meaning, purpose and value in 
their lives, on the other hand, were positively correlated with well-being-greater life satisfaction, more happiness, and less depression. The quest for meaning is not only morally worthwhile, but it also becomes rewarding as it progresses.

In general, meaning of life has been linked to psychological well-being, and it appears to play a role as a mediator in psychological health. (Ho, Cheung \& Cheung, 2010) University student which is categorized in youngster group of community is considered to be one of the most important stages of population growth, and low spiritual fitness levels may have an effect on well-being during maturity (Mathew, 2018). With COVID-19 case, it has pushed us all in ways we've never been pushed before, and forced us to do things we've never done before. It also draws attention to us in unusual ways. For students, particularly international students, this period of uncertainty really affects them due to the changes in teaching and learning process, and also due to the lockdown or movement control order. According to (Bradley, 2000), the international students are psychological vulnerable than local students.

The innovative COVID-19 epidemic has created a one-of-a-kind situation in our time, with multiple countries being placed under quarantine. Not only for health-care practitioners and COVID-19 patients, but also for the general public, this new position brings with it a host of psychological concerns. It can be difficult to adjust to a new situation. According to experts, people such as students experience emptiness and melancholy as a result of the loss of their normal lifestyles, which can lead to a loss of meaning in life. Indeed, during this pandemic, we can have a better understanding of our inner drive. There are advantages to this, such as a greater dependence on spiritual practice.

The aim of this study was to look at the links between meaning of life and life satisfaction among the international students at UPM during the COVID-19 pandemic. According to previous study, the existence of meaning in one's life and the search for meaning are negatively connected yet separate, signalling that their relationship can be examined (Steger et al., 2006). In this study, it was hypothesized that the search for meaning, particularly during times of uncertainty, would have a negative relationship on overall well-being. People who already have significant meaning in their life would find the search for meaning to be favourably connected with happiness. To put it another way, seeking deeper meaning is linked to psychological well-being and mental health.

\section{Literature Review}

\section{Meaning, Purpose and Value in Life}

Frankl (1984) highlighted empirical surveys in which the majority of respondents stated that their primary aims in life were to find purpose and meaning in life. Many psychologists may have assumed that life has no meaning other than the pursuit of happiness and the avoidance of misery. Others inspired by the Logotherapy, on the other hand, have emphasized the value of life's meaning and purpose. This could also due to fact that meaning has appeared too abstract or value laden to approach scientifically and empirically (Park \& Peterson, 2005). According to Logotherapy, the will to meaning is a key for human motivation. People may persevere and endure pain and adversity if they believe their struggles and suffering have meaning, purpose, and value. There are three core concepts underpin logotherapy. The first fundamental principle is that life has meaning in all situations, even those that are depressing. The second concept is that the need to find meaning in life is the most powerful motivator. 
Finally, the third universal concept asserts that mankind has the right to choose its attitude, particularly in the face of unchangeable adversity (Frankl, 1959).

Frankl (1984) affirms that the search for meaning has little to do with religion. From a religious standpoint, religion provides meaning and purpose to life. Persons who practice religion supposedly can easily derive meaning, purpose, and value from the rituals performed. However, not everyone who practices religion will be able to get meaning of life from the spiritual worth that religion provides. Instead, they would view religion solely through the lens of rituals.

\section{The Importance of Meaning of Life and Life Satisfaction}

The term "meaning" can be defined in a variety of ways. A meaningful existence, according to Peterson, Park, and Seligman (2005), is one in which people feel connected to something bigger than themselves. A life framed by meaning, according to them, is often more gratifying than a life framed by pleasure or happiness with passion. The age-old philosophical debate over whether to live a meaningful life based on inner virtue (eudemonia) or to live for pleasure's sake. Eudaimonia has been scientifically proven to be the best option (Peterson et al., 2005; cited from Park, 2010).

Empirical evidence backs up the importance of meaning in life for one's health and well-being. Several studies show a clear correlation between having a sense of meaning and happiness. Life satisfaction, optimism, happiness, and self-esteem are all higher in people who have a feeling of purpose and meaning in their lives (Steger \& Kashdan, 2007; Steger, Oishi, \& Kondo, 2007; cited from Park, 2010).

Cited from Devoe (2012), according to Frankl, people can find meaning through creative, experiential, and attitudinal traits (Hatt, 1965). Creative talents can be demonstrated by completing chores such as composing literary work or tending to a flowerbed (Boeree, 2006). Experiential values include meeting another human, such as when we enjoy the hug of a loved one, or experiencing the world through a state of openness, admiring natural beauty, such as when we revel in the grandeur of a sunset and contemplate on creation (Hatt, 1965). The ability to make meaningful decisions in the midst of hardship and misery is referred to as attitudinal values (Gelman \& Gallo, 2009).

\section{Why Meaning?}

The Greek word "logos" means "meaning." Thus, logotherapy is focused with an individual's search for meaning. The search for meaning in one's life is regarded to be the major motivator (Frankl, 1982). According to him, there are three important reasons why we need to have meaning. Firstly, meaning provides a purpose for our lives. Many studies have discovered a link between one's health and longevity and the purpose of one's life. For example, cited from Park (2010) a longitudinal research of 1,238 community-dwelling elders in the United States found that having a greater sense of meaning and purpose in life reduced the risk of death among the elderly (Boyle et al., 2009). Even after controlling for age, gender, education, and race, Peterson (2005) found that older persons who had a higher sense of life meaning and purpose were only half as likely to die over a five-year period as those who had a lower sense of life meaning and purpose. 
Meaning in life is more than a theoretical or philosophical concept; it has an impact on human health and wellness, and the lack of it is connected to instability and psychopathology. (Yalom, 1980) People who fail to identify the meaning of their lives, will have the symptoms of existential neurosis, such as suicidal tendencies, juvenile delinquency, loss of reason to move on, distress symptoms, and dependency, symptoms of neurotic and psychotic difference, psychological combustion, physical ailments, stress, drug abuse, and alcoholism (Frankl, 1982; Patterson, 1990; Fujita, 1992; cited from Kadhim, 2019).

Second, life's meaning provides values or standards by which we can evaluate our activities. In an empirical study, Yalom (1980) verified prior clinical observations that living without meaning, goals, or values causes significant distress. Thirdly, it provides us a sense of control over events in our lives when human life is confronted with unprecedented circumstances, as Frankl asserts that those who understand the "why" may understand the "how."

One may wonder, in an attempt to come up with a single definition of what is the essence of meaning, there is no single common answer to this question. Because the meaning of life varies from person to person, day to day, and hour to hour. What matters, then, is not the general meaning of life, but the individual meaning of a person's life at each given time (Frankl, 1978). According to logotherapy, the will to meaning is a key human motivator. People will persevere through pain and adversity if they believe their struggle and suffering have meaning and value.

On the other hand, if the individuals are able to find the meaning of every aspect of their life, they will perceive their life to be more meaningful, hence they will keep looking for the greater meaning of life by giving others the meaning of life (Hassan, 2010). Therefore, sources the meaning of life appear in the service or the help of others, mutual relations, to live according to the beliefs of limited, expression and creativity through art, music, poetry. Meaning of life can also be found in material possession of the causes of happiness, existential direction based on pleasure, and lastly, personal progress as evidence of achievement. With this, humans will see the value of gaining a meaning, and as a result, they will develop the responsibility and dedication necessary to participate in the world.

\section{Life Satisfaction}

One might ask, what variables, for example, impact the development of life meaning that leads to life satisfaction? Generally speaking, there is no one who is born with a sense of purpose. However, if we consider it from a theological standpoint, we might conclude that there must be a cause for our creation. For example, Islam emphasizes that man was created for two purposes: to serve as God's servant and vicegerent.

The presence of meaning in one's life is associated with positive psychological outcomes such as life satisfaction, whereas the quest for meaning is frequently associated with negative results such as depression (Steger, Frazier \& Oishi; 2006; Steger et al., 2009). It means that on one level, these findings are unsurprising because people may seek significance while they are experiencing adversity.

In the case of the COVID-19 pandemic, one way to overcome this catastrophe is through the activation of spiritual knowledge components that all humans possess but are underutilized. Indeed, the COVID-19 pandemic provides the ideal opportunity for anybody to adapt, accept, and transform life and tragedy into a moment of resilience, strength, knowledge, and a new 
environment of shared and collective life, shared responsibility, and appreciation of solidarity. In this situation, students particularly, must believe in themselves, acquire sensitivity and cognitive regulation, and manage more positively with calamity, major tragedies, and uncertainty in order to live with the best versus the worst.

\section{Method}

\section{Sample}

From December 2020 to January 2021, a Google Form survey was conducted. This crosssectional study only involves international undergraduate students from various faculties. There were 298 students registered in this compulsory UPM course FEM2310 Malaysian Values, Culture, and Society in the first semester of the academic year 2020/2021, however only 206 were willing to participate in this survey, with 103 male students and 100 female students.

\section{Procedure}

The survey covers 3 sections. In the section it is the respondents' demographics profile. In the second section the questionnaire survey attempts to plot the respondents' level of meaning of life using the Meaning in life (MLQ) instrument developed by Steger (2010).

In this study Meaning of life was measured using the Meaning in Life Questionnaire (MLQ; Steger et al., 2006). This 10-item comprises of five items indicating the presence of meaning example: "I understand my life's meaning" and five items measuring the search for meaning: example: "I am always looking to find my life's purpose". Participants respond to each item on a scale from 1 = "absolutely untrue" to 7 = "absolutely true". Scores are added separately for the two meaning subscales. In the present sample, internal consistency estimated by coefficient alpha .91 for the presence of meaning and .90 for the search for meaning.

For the Life satisfaction, the Satisfaction with Life Scale (SWLS), which was first created by researchers Diener, Emmons, Larsen, and Griffin (1985) was used. The SWLS measures the individual's evaluation of satisfaction with his or her life in general such as, "I am satisfied with my life". It consists of five items for which respondents select one of seven options, ranging from 1 = "strongly disagree" to 7 = "strongly agree") for each item. Responses are summed to provide a total life satisfaction score. Internal consistency in the present sample was $\mathrm{a}=.86$

Respondents were told that it was their choice whether or not to engage in the study by filling out a questionnaire in terms of ethical protocols. They were also told about the study's goal and how it would help them as individuals and society as a whole. 


\section{Findings}

Demographic Profile of Respondents

Table 4.1: Demographic Respondents

\begin{tabular}{lcc}
\hline Variables & Frequency (n) & Percentage (\%) \\
\hline Gender & 103 & 50.7 \\
$\quad$ Male & 100 & 49.3 \\
$\quad$ Female & & \\
Age & 96 & 47.3 \\
$\quad 18-20$ & 99 & 48.8 \\
$21-23$ & 8 & 3.9 \\
$24-26$ & & \\
Faculty & 119 & 58.3 \\
$\quad$ Economics & 40 & 19.6 \\
$\quad$ Computer Science & & 22.1 \\
Others (Modern Language, & 45 & \\
Agriculture, Human Ecology, \\
etc)
\end{tabular}

Based on table 4.1 which is the demographics of the respondents, a total of 204 respondents participated in this study. The table above shows the gender of the respondents. 2 categories of gender are listed, which are male and female. The table above shows the highest gender with a total of 103 (50.7\%) of male respondents and a total of 100 (49.3\%) of female respondents.

As for the age of this respondent, which only comprises of undergraduate students, there are 3 age categories which is $18-20$ years, $21-23$ years, and $24-26$ years. The table above shows a total of $96(47.3 \%)$ respondents aged $18-20$ years, 99 (48.8\%) respondents aged 21-23 years, and $8(3.9 \%)$ respondents aged $24-26$ years. The results of the study found that the age respondents of 21-23 years were the highest at $99(48.8 \%)$ while respondents aged respondents of $24-26$ years were the lowest at 8 (3.9\%).

There are three categories of faculty which are, Economics, Computer Science, and Others (Modern Language and Communication, Agriculture, Human Ecology, etc.). In the table above, there are 119 (58.3\%) respondents from the Faculty of Economics, 40 (19.6\%) respondents from the Faculty of Computer Science and 45 (22.1\%) respondents from other faculties (e.g., Modern Languages, Agriculture, Human Ecology, and so on). The Faculty of 
Economics had the highest number of responses $(119$, or $58.3 \%)$, while the Faculty of Computer Science had the lowest number of respondents $40,(19.6 \%)$.

In term of nationality of the respondents, there are 4 categories of nationality which are Chinese, Arab (Iraqi, Yemeni, Syrian, Emirati, Jordanian, Saudian, Algerian, Lebanese, etc), Indian (Bangladeshi, Pakistani, Sri Lankan, etc) and Asian (Indonesian, Bruneian, Philippines, Japanese, etc). The table above shows a total of 154 (76.6\%) respondents from Chinese, 14 (7\%) respondents from Arab (Iraqi, Yemeni, Syrian, Emirati, Jordanian, Saudian, Algerian, Lebanese, etc), 13 (6.5\%) respondents from Indian (Bangladeshi, Pakistani, Sri Lankan, etc) and 20 (10\%) respondents from Asian (Indonesian, Bruneian, Philippines, Japanese, etc). The results showed that the Chinese are the highest with 154 (76.6\%) respondents while the lowest is the Indian (Bangladeshi, Pakistani, Sri Lankan, etc) with $13(6.5 \%)$ respondents.

The Meaning of Life among the Students

Table 4.2: Meaning of Life

\begin{tabular}{|c|c|c|c|c|c|c|}
\hline \multirow[b]{2}{*}{ No } & \multirow[b]{2}{*}{ Question } & \multicolumn{5}{|c|}{ Frequency (n) and Percentage (\%) } \\
\hline & & $\begin{array}{l}\text { Absolutely } \\
\text { Untrue }\end{array}$ & $\begin{array}{c}\text { Somewhat } \\
\text { Untrue }\end{array}$ & $\begin{array}{c}\text { Can't } \\
\text { Say True } \\
\text { Or False }\end{array}$ & $\begin{array}{c}\text { Somewhat } \\
\text { True }\end{array}$ & $\begin{array}{c}\text { Absolutely } \\
\text { True }\end{array}$ \\
\hline 1 & $\mathrm{I}$ & & & & & \\
\hline & $\begin{array}{l}\text { understand } \\
\text { my life's } \\
\text { meaning. }\end{array}$ & $\begin{array}{c}0 \\
(0 \%)\end{array}$ & $\begin{array}{c}5 \\
(2.5 \%)\end{array}$ & $\begin{array}{c}31 \\
(15.2 \%\end{array}$ & $\begin{array}{c}68 \\
(33.3 \%)\end{array}$ & $\begin{array}{c}100 \\
(49 \%)\end{array}$ \\
\hline 2 & $\begin{array}{l}\text { I am looking } \\
\text { for }\end{array}$ & & & & & \\
\hline & $\begin{array}{l}\text { something } \\
\text { that makes } \\
\text { my life feel } \\
\text { meaningful. }\end{array}$ & $\begin{array}{c}5 \\
(2.5 \%)\end{array}$ & $\begin{array}{c}3 \\
(1.5 \%)\end{array}$ & $\begin{array}{c}17 \\
(8.3 \%)\end{array}$ & $\begin{array}{c}64 \\
(31.4 \%)\end{array}$ & $\begin{array}{c}115 \\
(56.4 \%)\end{array}$ \\
\hline 3 & $\begin{array}{l}\text { I am always } \\
\text { looking to } \\
\text { find my } \\
\text { life's } \\
\text { purpose. }\end{array}$ & $\begin{array}{c}7 \\
(3.4 \%)\end{array}$ & $\begin{array}{c}4 \\
(2 \%)\end{array}$ & $\begin{array}{c}33 \\
(16.3 \%)\end{array}$ & $\begin{array}{c}59 \\
(29.1 \%)\end{array}$ & $\begin{array}{c}100 \\
(49.3 \%)\end{array}$ \\
\hline 4 & $\begin{array}{l}\text { My life has } \\
\text { a clear } \\
\text { sense of } \\
\text { purpose. }\end{array}$ & $\begin{array}{c}1 \\
(0.5 \%)\end{array}$ & $\begin{array}{c}10 \\
(4.9 \%)\end{array}$ & $\begin{array}{c}60 \\
(29.6 \%)\end{array}$ & $\begin{array}{c}67 \\
(33 \%)\end{array}$ & $\begin{array}{c}65 \\
(32 \%)\end{array}$ \\
\hline 5 & $\begin{array}{l}\text { I have a } \\
\text { good sense } \\
\text { of what } \\
\text { makes my } \\
\text { life } \\
\text { meaningful. }\end{array}$ & $\begin{array}{c}2 \\
(1 \%)\end{array}$ & $\begin{array}{c}7 \\
(3.5 \%)\end{array}$ & $\begin{array}{c}35 \\
(17.5 \%)\end{array}$ & $\begin{array}{c}75 \\
(37.5 \%)\end{array}$ & $\begin{array}{c}81 \\
(40.5 \%)\end{array}$ \\
\hline 6 & $\begin{array}{l}\text { I have } \\
\text { discovered }\end{array}$ & $\begin{array}{c}3 \\
(1.5 \%)\end{array}$ & $\begin{array}{c}14 \\
(7 \%)\end{array}$ & $\begin{array}{c}39 \\
(19.4 \%)\end{array}$ & $\begin{array}{c}77 \\
(38.3 \%)\end{array}$ & $\begin{array}{c}68 \\
(33.8 \%)\end{array}$ \\
\hline
\end{tabular}




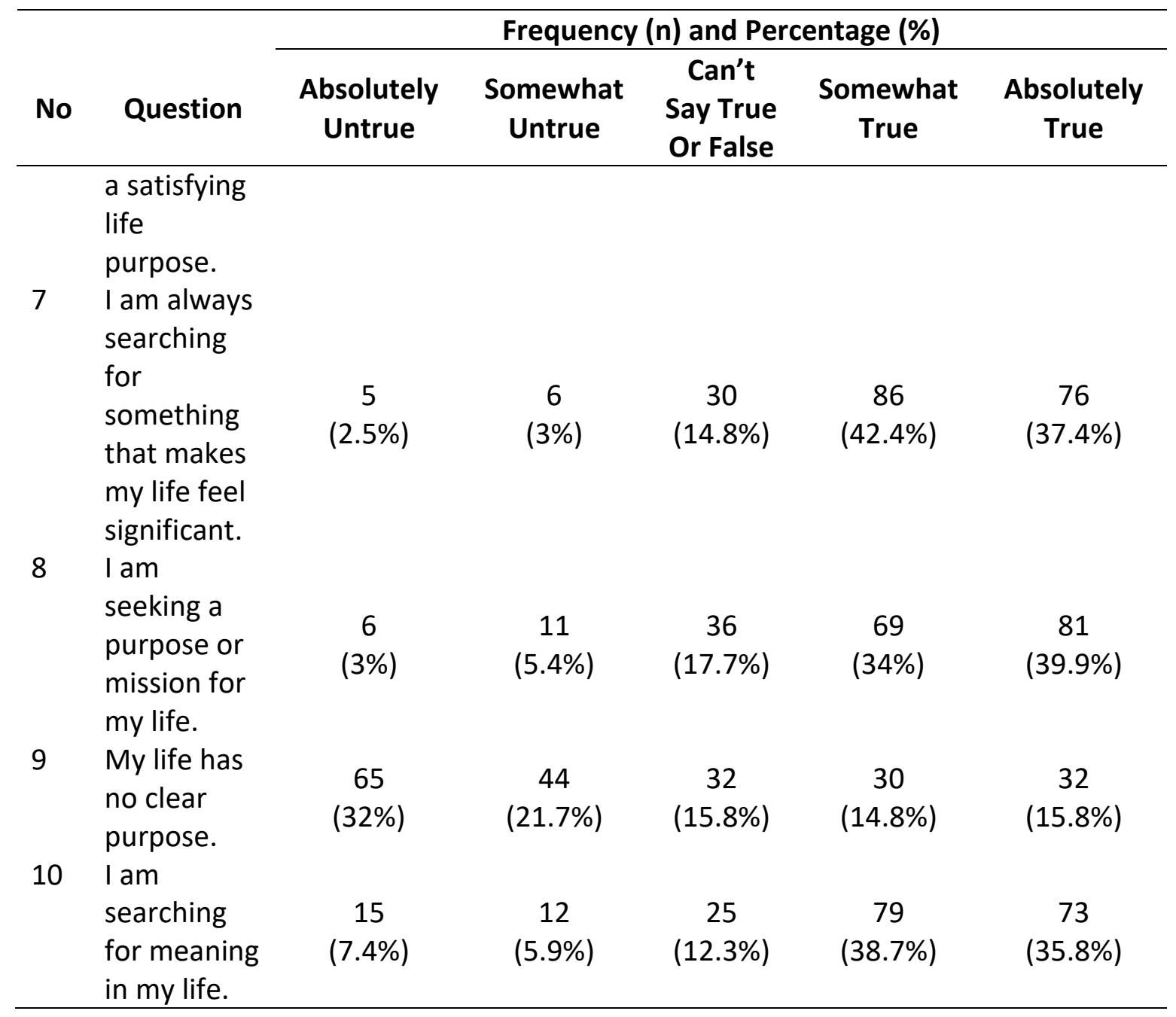

The findings revealed that almost all respondents have a meaning of life. Based on the table 4.2 above, for question 1, "I understand my life's meaning" a total of $0(0 \%)$ respondents chose the scale "absolutely untrue", $5(2.5 \%)$ respondents chose the scale "somewhat untrue", 31 (15.2\%) respondents chose the scale "can't say true or false", 68 (33.3\%) respondents chose the scale of somewhat true and 100 (49\%) respondents chose the scale "absolutely true". For question 2, "I am looking for something that makes my life feel meaningful", a total of $5(2.5 \%)$ respondents chose the scale "absolutely untrue", 3 (1.5\%) respondents chose the scale "somewhat untrue", 17 (8.3\%) respondents chose the scale "can't say true or false", 64 (31.4\%) respondents chose the scale of "somewhat true" and 115 (56.4\%) respondents chose the scale "absolutely true".

For question 3, "I am always looking to find my life's purpose" a total of 7 (3.4\%) respondents chose the scale "absolutely untrue", $4(2 \%)$ respondents chose the scale "somewhat untrue", $33(16.3 \%)$ respondents chose the scale "can't say true or false", 59 (29.1\%) respondents chose the scale of "somewhat true and 100 (49.3\%) respondents chose the scale absolutely true. For question 4, "My life has a clear sense of purpose" a total of 1 (0.5\%) respondents chose the scale "absolutely untrue", 10 (4.9\%) respondents chose the scale "somewhat untrue", 60 (29.6\%) respondents chose the scale "can't say true or false", 67 (33\%) respondents chose the scale of "somewhat true" and 65 (32\%) respondents chose the scale "absolutely true". 
For Question 5, "I have a good sense of what makes my life meaningful", a total of 2 (1\%) respondents chose the scale "absolutely untrue", 7 (3.5\%) respondents chose the scale "somewhat untrue", 35 (17.5\%) respondents chose the scale "can't say true or false", 75 $(37.5 \%)$ respondents chose the scale of "somewhat true" and 81 (40.5\%) respondents chose the scale "absolutely true". For the question 6, "I have discovered a satisfying life purpose", a total of $3(1.5 \%)$ respondents chose the scale "absolutely Untrue", 14 (7\%) respondents chose the scale "somewhat untrue", 39 (19.4\%) respondents chose the scale "can't say true or false", 77 (38.3\%) respondents chose the scale of "somewhat true" and 68 (33.8\%) respondents chose the scale "absolutely true".

For question 7, "I am always searching for something that makes my life feel significant" a total of $5(2.5 \%)$ respondents chose the scale "absolutely untrue", $6(3 \%)$ respondents chose the scale "somewhat untrue", $30(14.8 \%)$ respondents chose the scale "can't say true or false", 86 (42.4\%) respondents chose the scale of "somewhat true" and 76 (37.4\%) respondents chose the scale "absolutely true". In question 8 , "I am seeking a purpose or mission for my life" a total of $6(3 \%)$ respondents chose the scale "absolutely untrue", 11 (5.4\%) respondents chose the scale "somewhat untrue", 36 (17.7\%) respondents chose the scale "can't say true or false", 69 (34\%) respondents chose the scale of "somewhat true" and $81(39.9 \%)$ respondents chose the scale "absolutely true".

In question 9, "My life has no clear purpose" a total of 65 (32\%) respondents chose the scale "absolutely untrue", 44 (21.7\%) respondents chose the scale "somewhat untrue", 32 (15.8\%) respondents chose the scale "can't say true or false", $30(14.8 \%)$ respondents chose the scale of "somewhat true" and $32(15.8 \%)$ respondents chose the scale "absolutely true". Next, question 10, "I am searching for meaning in my life" a total of 15 (7.4\%) respondents chose the scale "absolutely untrue", 12 (5.9\%) respondents chose the scale "somewhat untrue", 25 $(12.3 \%)$ respondents chose the scale "can't say true or false", 79 (38.7\%) respondents chose the scale of "somewhat true" and $73(35.8 \%)$ respondents chose the scale "absolutely true".

\section{Life Satisfaction}

Based on table 4.3 which is Life Satisfaction, for question 1, "In most ways my life is close to my ideal" a total of 8 (3.9\%) respondents chose the scale "strongly disagree", 17 (8.4\%) respondents chose the scale "disagree", 71 (35\%) respondents chose the scale "neither agree nor disagree", 69 (34\%) respondents chose the scale "agree", and 38 (18.7\%) respondents chose the scale "strongly agree". For the question 2, "The conditions of my life are excellent" a total of $1(0.5 \%)$ respondents chose the scale "strongly disagree", 13 (6.4\%) respondents chose the scale "disagree", 60 (29.4\%) respondents chose the scale "neither agree nor disagree", $78(38.2 \%)$ respondents chose the scale "agree", and 52 (25.5\%) respondents chose the scale "strongly agree". 
Table 4.3: Satisfaction with Life

\begin{tabular}{|c|c|c|c|c|c|c|}
\hline \multirow[b]{2}{*}{ No } & \multirow[b]{2}{*}{ Question } & \multicolumn{5}{|c|}{ Frequency (n) and Percentage (\%) } \\
\hline & & $\begin{array}{l}\text { Strongly } \\
\text { Disagree }\end{array}$ & Disagree & $\begin{array}{c}\text { Neither } \\
\text { Agree }\end{array}$ & Agree & $\begin{array}{c}\text { Strongly } \\
\text { Agree }\end{array}$ \\
\hline 1 & $\begin{array}{l}\text { In most ways } \\
\text { my life is close } \\
\text { to my ideal. }\end{array}$ & $\begin{array}{c}8 \\
(3.9 \%)\end{array}$ & $\begin{array}{c}17 \\
(8.4 \%)\end{array}$ & $\begin{array}{c}71 \\
(35 \%)\end{array}$ & $\begin{array}{c}69 \\
(34 \%)\end{array}$ & $\begin{array}{c}38 \\
(18.7 \%)\end{array}$ \\
\hline 2 & $\begin{array}{l}\text { The conditions } \\
\text { of my life are } \\
\text { excellent. }\end{array}$ & $\begin{array}{c}1 \\
(0.5 \%)\end{array}$ & $\begin{array}{c}13 \\
(6.4 \%)\end{array}$ & $\begin{array}{c}60 \\
(29.4 \%)\end{array}$ & $\begin{array}{c}78 \\
(38.2 \%)\end{array}$ & $\begin{array}{c}52 \\
(25.5 \%)\end{array}$ \\
\hline 3 & $\begin{array}{l}\text { I am satisfied } \\
\text { with life. }\end{array}$ & $\begin{array}{c}4 \\
(2 \%)\end{array}$ & $\begin{array}{c}11 \\
(5.4 \%)\end{array}$ & $\begin{array}{c}52 \\
(25.6 \%)\end{array}$ & $\begin{array}{c}71 \\
(35 \%)\end{array}$ & $\begin{array}{c}65 \\
(32 \%)\end{array}$ \\
\hline 4 & $\begin{array}{l}\text { So far I have } \\
\text { gotten the } \\
\text { important } \\
\text { things I want in } \\
\text { life. }\end{array}$ & $\begin{array}{c}5 \\
(2.5 \%)\end{array}$ & $\begin{array}{c}16 \\
(7.8 \%)\end{array}$ & $\begin{array}{c}57 \\
(27.9 \%)\end{array}$ & $\begin{array}{c}77 \\
(37.7 \%)\end{array}$ & $\begin{array}{c}49 \\
(24 \%)\end{array}$ \\
\hline 5 & $\begin{array}{l}\text { If I could live } \\
\text { my life over, I } \\
\text { would change } \\
\text { almost nothing. }\end{array}$ & $\begin{array}{c}24 \\
(11.8 \%)\end{array}$ & $\begin{array}{c}35 \\
(17.2 \%)\end{array}$ & $\begin{array}{c}56 \\
(27.5 \%)\end{array}$ & $\begin{array}{c}53 \\
(26 \%)\end{array}$ & $\begin{array}{c}36 \\
(17.6 \%)\end{array}$ \\
\hline
\end{tabular}

For question 3, "I am satisfied with life" a total of $4(2 \%)$ respondents chose the scale "strongly disagree", 11 (5.4\%) respondents chose the scale "disagree", 52 (25.6\%) respondents chose the scale "neither agree nor disagree", 71 (35\%) respondents chose the scale "agree", and 65 (32\%) respondents chose the scale "strongly agree". For question 4, "So far I have gotten the important things I want in life" a total of $5(2.5 \%)$ respondents chose the scale "strongly disagree", 16 (7.8\%) respondents chose the scale "disagree", 57 (27.9\%) respondents chose the scale "neither agree nor disagree", 77 (37.7\%) respondents chose the scale "agree", and $49(24 \%)$ respondents chose the scale "strongly agree".

For question 5, "If I could live my life over, I would change almost nothing", a total of 24 $(11.8 \%)$ respondents chose the scale "strongly disagree", 35 (17.2\%) respondents chose the scale "disagree", 56 (27.5\%) respondents chose the scale "neither agree nor disagree", 53 (26\%) respondents chose the scale "agree", and $36(17.6 \%)$ respondents chose the scale "strongly agree".

Table 4.4: Level of Meaning of Life

\begin{tabular}{lccccc}
\hline & & \multicolumn{4}{c}{ Statistical Value Meaning Of Life } \\
\cline { 3 - 6 } Subscale & Frequency (n) & Mean & Minimum & Maximum & $\begin{array}{c}\text { Std. } \\
\text { Deviation }\end{array}$ \\
\hline Presence & 204 & 19 & 11 & 25 & 3.346 \\
Search & 204 & 21 & 5 & 25 & 3.973 \\
\hline
\end{tabular}

Based on table 4.4, the level of meaning of life of the respondents, there are 2 levels which is presence and search. The table above shows, a total of 204 respondents at the presence state of meaning of life. Statistical values for the presence showed a mean score of 19 , minimum 
11, maximum 25 with a standard deviation of 3.346. Next, a total of 204 respondents at the search state meaning of life. Statistical values for the level of life satisfaction showed a mean score of 21, minimum 5, maximum 25 with a standard deviation of 3.973. The results showed that the search are the highest standard deviation at 3.973 while the presence is the lowest standard deviation at 3.346.

Table 4.5: Level of Life Satisfaction

\begin{tabular}{lcc}
\hline Level & Frequency $(\mathbf{n})$ & Percentage (\%) \\
\hline Extremely satisfied & 54 & 26.5 \\
Satisfied & 101 & 49.5 \\
Slightly satisfied & 44 & 21.6 \\
Neutral & 0 & 0 \\
Slightly dissatisfied & 5 & 2.4 \\
Dissatisfied & 0 & 0 \\
Extremely dissatisfied & 0 & 0 \\
\hline Total & $\mathbf{2 0 4}$ & $\mathbf{1 0 0}$ \\
\hline
\end{tabular}

Based on table 4.5 and table 4.6, the level of life satisfaction of the respondents, are 7 which are "extremely satisfied", "satisfied", "slightly satisfied", "neutral", "slightly dissatisfied", "dissatisfied", and "extremely dissatisfied". The table above shows, a total of 54 (26.5\%) respondents at the "extremely satisfied" level, 101 (49.5\%) respondents at the "satisfied" level, 44 (21.6\%) respondents at the "slightly satisfied" level and 5 (2.4\%) respondents at the "slightly dissatisfied" level. The results of the study found that the highest level of life satisfaction of respondents is at the "satisfied level" of 101 respondents (49.5\%) while the lowest level is at the "slightly dissatisfied level" of 5 respondents (2.4\%). Statistical values for the level of life satisfaction showed a mean score of 19, minimum 5, maximum 25 with a standard deviation of 3.988 .

Table 4.6: Level Statistical Values of Life Satisfaction

\begin{tabular}{lc}
\hline Statistical Value & \\
\hline Mean & 19 \\
Minimum & 5 \\
Maximum & 25 \\
Std. Deviation & 3.988 \\
\hline
\end{tabular}

Based on table 4.7, the results of the study found that there is a positive relationship between the two variables. In addition, there is a significant relationship between meaning of life and life satisfaction of 0.01 because the significant value shown in the table above is less than 0.05 . 
Table 4.7: Correlation Pearson Meaning of Life and Life Satisfaction

\begin{tabular}{|c|c|c|c|}
\hline \multicolumn{4}{|c|}{ CORRELATIONS PEARSON } \\
\hline & & $\begin{array}{c}\text { Meaning of } \\
\text { Life }\end{array}$ & $\begin{array}{c}\text { Life } \\
\text { Satisfaction }\end{array}$ \\
\hline \multirow{3}{*}{ MEANING OF LIFE } & Pearson Correlation & 1 & $.570^{* *}$ \\
\hline & Sig. (2-tailed) & & .000 \\
\hline & $\mathrm{N}$ & 195 & 194 \\
\hline \multirow{3}{*}{$\begin{array}{l}\text { LIFE } \\
\text { SATISFACTION }\end{array}$} & Pearson Correlation & $.570^{* *}$ & 1 \\
\hline & Sig. (2-tailed) & .000 & \\
\hline & $\mathrm{N}$ & 194 & 202 \\
\hline
\end{tabular}

**. CORRELATION IS SIGNIFICANT AT THE 0.01 LEVEL (2-TAILED).

\section{Discussion}

The study found that having a sense of purpose and meaning in life is linked to feeling satisfied with one's life. The findings revealed that life satisfaction and experienced meaning have a favourable relationship. Despite the fact that there is few research in the literature, this conclusion is supported by it. Steger et al. (2006) established a relationship between life satisfaction and experienced meaning. Individuals who believe their lives have meaning and purpose are more inclined to live fully and consider their lives to be valuable, vital, and worthy (Park, 2010).

Indeed, the COVID-19 pandemic could lead students, particularly international students, to adjust, embrace, and change their lives, turning the tragedy into a time of resilience, strength, knowledge. It also provides a new environment of mutual and communal living, sharing responsibilities, and appreciating solidarity by providing a clear meaning of life. This is critical in order to retain life happiness in the face of uncertainty.

Certainly, the outcomes of this research give a broad picture of how important it is to have a sense of purpose in life amid the COVID-19 epidemic. COVID-19 is only one example of instability, catastrophe, uncertainty and confusion. What is important is that we have learned the lesson from it and how we treat it. In this case, we have been able to understand how important to have this construct, meaning of life, particularly for students. This is consistent with a basic principle of Logotherapy, which holds that the desire for meaning is a powerful human motivation and drive. People will persevere through pain and adversity if they believe their struggle and suffering have meaning and value.

From this finding, as a way forward, greater effort must be made to ensure that during their time as university students, they would be able to empower themselves with a spiritual component, a complement component for physical and intellectual. This is important in order to develop a balanced, full of life satisfaction and healthy personality. Certainly, this is in line with the empirical study by Yalom (1980), verified prior clinical observations that, living without meaning, goals, or values causes significant distress. In addition to that, with meaning of life, it provides us a sense of control over events in our lives when human life is confronted with unprecedented circumstances, as Frankl asserts that those who understand the "why" may understand the "how." 
Indeed, the meaning of life is a vital component of the spiritual realm, and it has evolved into a crucial aspect of spiritual intelligence, a grace or noble character that aids students to adapt or integrate with others, no matter what their lives may be.

\section{Conclusion}

The outcomes of this study give a comprehensive picture of how important it is to have a meaning of life in order to satisfy with life and sustain happiness, especially during the COVID19 pandemic. Indeed, COVID-19 is only one example of instability, catastrophe, uncertainty and confusion. However, with a clear meaning of life, international students who are considered as having more psychological vulnerable than local students are able to cope with this and at the same time gain a satisfaction of their life in spite of uncertainties and catastrophes.

This paper also suggests that having meaning of life is the road to attaining life satisfaction and cultivating our faith and that it is a technique for dealing with instability an uncertainty such as the COVID-19 pandemic. It is during times like these that Viktor Frankl's words resonate true: "It is we who must answer the questions that life poses to us, and we can only react to those questions by taking responsibility for our own existence." Indeed, we are living in an incredible period of history, ripe with opportunities to learn more about ourselves and people around us.

\section{References}

Kadhim, A. S. (2019). The Meaning of Life and Its Relationship to the Cognitive Motivation among University Students. Journal of Arts, Humanities, and Social Science. DOI: 10.33193/JALHSS.36.16

Baumeister, R. F., \& Vohs, K. D. (2002). The pursuit of meaningfulness in life. Handbook of positive psychology, 1, 608-618.

Boeree, C. G. (2006). Personality theories: Viktor Frankl. Shippensburg: Psychology Department Shippensburg University. Retrieved from http://webspace.ship.edu/cgboer/frankl.html

Bradley, G. (2000). Responding effectively to the mental health needs of international students. Higher Education, 39(4), 417-433.

Devoe, D. (2012). Viktor Frankl's logotherapy: The search for purpose and meaning. Inquiries Journal, 4(07). Retrieved from http://www.inquiriesjournal.com/a?id=660.

Diener, E. D., Emmons, R. A., Larsen, R. J., \& Griffin, S. (1985). The satisfaction with life scale. Journal of personality assessment, 49(1), 71-75.

Frankl, V. E. (1965). The doctor and the soul: From psychotherapy to logotherapy. New York: Vintage Books.

Frankl, V. E. (1982). Man's Search for Meaning, Fourth Edition.

Fujita, F., \& Diener, E. (1992). Social comparison and domain satisfactions. Research in progress.

George, J. M. (1991). Time structure and purpose as a mediator of work-life linkages. Journal of Applied Social Psychology, 21(4), 296-314.

Gelman, M., \& Gallo, J. (2009). Finding meaning in life at midlife and beyond: Wisdom and spirit from logotherapy. Journal of Judaism \& Civilization, 8(59), 91-93.

Hatt, H. (1965). Existential analysis and logotherapy: The contribution of Viktor $E$ Frankl. Encounter, 26(3), 330-339. 
Park, N., Park, M., \& Peterson, C. (2010). When is the search for meaning related to life satisfaction?. Applied Psychology: Health and Well-Being, 2(1), 1-13. https://doi.org/10.1111/j.1758-0854.2009.01024.x

Peterson, C., Park, N., \& Seligman, M. E. (2005). Orientations to happiness and life satisfaction: The full life versus the empty life. Journal of happiness studies, 6(1), 25-41.

Steger, M. F., Frazier, P., Oishi, S., \& Kaler, M. (2006). The meaning in life questionnaire: assessing the presence of and search for meaning in life. Journal of counseling psychology, 53(1), 80.

Wong, P. T. (1998). Meaning-centered counselling. The human quest for meaning: $A$ handbook of psychological research and clinical applications, 395-435.

Yalom, I. D. (2020). Existential psychotherapy. Hachette UK. 